\title{
A new simplified method for efficient extraction of solar cells and modules parameters from datasheet information
}

Fahmi F. Muhammadsharif ( $\square$ fahmi982@gmail.com )

Koya University https://orcid.org/0000-0002-4563-9671

\section{Research Article}

Keywords: Solar cell, PV module, parameter extraction, simple approach, datasheet information

Posted Date: February 19th, 2021

DOl: https://doi.org/10.21203/rs.3.rs-167253/v1

License: (c) (i) This work is licensed under a Creative Commons Attribution 4.0 International License.

Read Full License

Version of Record: A version of this preprint was published at Silicon on April 8th, 2021. See the published version at https://doi.org/10.1007/s12633-021-01097-1. 


\section{A new simplified method for efficient extraction of solar cells and}

2 modules parameters from datasheet information

3

4

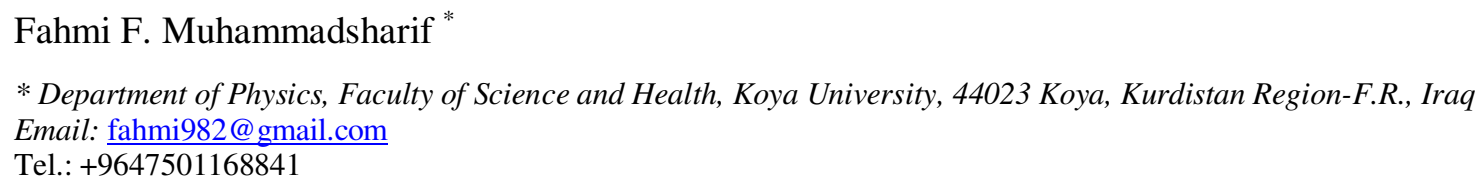

\section{Abstract}

An accurate and straightforward estimation of solar cells and modules parameters from the manufacturer's datasheet is essential for the performance assessment, simulation, design, and quality control. In this work, a simple and efficient technique is reported to extract the parameters of solar cells and modules, namely ideality factor $(n)$, series resistance $\left(R_{s}\right)$, shunt resistance $\left(R_{s h}\right)$, photocurrent $\left(I_{p h}\right)$ and saturation current $\left(I_{o}\right)$, from datasheet information. The method is based on defining the peak position of the function $f\left(n, R_{s h}\right)=n\left(R_{\text {sh_max }}-R_{s h}\right)$, at which the five parameters are extracted. It was validated on four different technologies of solar cells and modules, including Poly-Si, Mono-Si, thin film and multijunction. Results showed that a simple and efficient extraction of the parameters can be realized by using this technique compared to that of the reported methods in literature.

Keywords: Solar cell, PV module, parameter extraction, simple approach, datasheet information.

\section{Introduction}

Solar energy is a promising resource to fulfil the future demand of human on energy owing to its diverse utilization, cleanliness, environmentally friendliness and freely abundancy. The conversion of sunlight energy to electricity is implemented by means of solar cells and modules 
in a technology known as photovoltaic (PV) technology. There are different types of solar

34 modules available on the market, namely mono-crystalline silicon, multi-crystalline and amorphous [1-3]. Modeling of the current-voltage $(I-V)$ characteristics of solar modules is essential for the performance assessment, simulation, design, and quality control [4-7]. This can only be achieved if the parameters of these devices are accurately determined. Estimating the parameters of PV modules is also vital to predict the energy yield [8], to build algorithms for maximum power point trackers (MPPTs) $[9,10]$, to develop plug-in hybrid electric vehicles (PHEVs) [11], to address the degradation and aging issues in PV devices [12,13] and to understand the outdoor operation of PV panels in various environmental conditions [14]. The parameters of solar cells and modules are ideality factor $(n)$, series resistance $\left(R_{s}\right)$, shunt resistance $\left(R_{s h}\right)$, photocurrent $\left(I_{p h}\right)$ and saturation current $\left(I_{o}\right)$. Because these parameters are highly sensitive to the irradiance, light energy, cells temperature and aging [15-17,5,18-20], researchers usually face a big challenge in modelling the $I$ - $V$ characteristics of solar modules in different environmental conditions.

Along this line, researchers usually depend on two main datasets to determine the parameters of solar cells and modules. The first dataset is the experimentally measured $I$ - $V$ data, while the second dataset is obtained from the datasheet information, which is provided by the manufacturers of the solar cells and modules. It is known that the parameters of solar modules can be accurately extracted from the measured $I-V$ data [21-25]. However, the datasheet information does not include the measured $I-V$ data of the module. Alternatively, manufacturers of solar cells and modules provide a datasheet information, which includes the short circuit current $\left(I_{s c}\right)$, open circuit voltage $\left(V_{o c}\right)$, voltage at maximum power $\left(V_{m}\right)$, current at maximum power $\left(I_{m}\right)$ and temperature coefficients of current, voltage and power at standard test condition (STC). Consequently, methods that depend on the datasheet information to determine the solar module parameters are of great importance for the researchers, technicians, end-users and PV 
designers in order to assess the solar modules under diverse conditions, thereby predicting the performance of PV systems before their real implementation [26].

60 The challenge is therefore how one simply and efficiently extract the parameters of solar cells and modules from the datasheet information [27,28]. Researchers proposed different analytical and numerical methods to determine these parameters with the help of single-diode model (SDM) [29-31,28,32,27]. Also, evolutionary and heuristic algorithms were utilized to extract the parameters of solar modules [33-44], but these techniques suffer from a high computational cost and reduced stability. We previously reported two computational methods that can be used to efficiently determine the modules parameters from measured $I-V$ data $[21,22]$. However, these methods are not applicable to extract the parameters from datasheet information. A review of literature revealed that iterative approaches can be adopted to achieve a simpler estimation of the parameters compared to that of the computational and deterministic methods. For instance, Sera et al. involved $R_{s}, R_{s h}$ and $n$ iteratively, thereby extracting the rest of parameters [45]. On the other hand, Villalva et al. considered a random value for the ideality factor while iterating the values of $R_{s}$ and $R_{s h}$ to the point where the simulated and experimental power are coincided at STC [46]. Chaibi et al. reported a simplified method to extract the PV parameters by iterating only the shunt resistance [47]. However, in order to determine the parameters, minimum and maximum $R_{s h}$ values are required to be selected manually based on the type of the investigated solar module technology. We have observed that the accuracy of simulated current is highly sensitive to the values of $n$ and $R_{s}$, but less sensitive to the $I_{p h}, I_{o}$ and $R_{s h}$ [22]. Taking into account the strong dependency of all the parameters on the ideality factor, we came to the hypothesis that iterating the ideality factor $(n)$, in fine-tuned steps, might be helpful in achieving a simpler, more accurate and computationally cost-effective approach to determine the electrical parameters of solar cells and modules using datasheet information only. Therefore, in the current work, a new method is reported to determine the parameters of 
83 solar cells and modules from the datasheet information. The approach is initialized by a fine-

84 tuned iteration of ideality factor through which all other parameters are extracted without any

85 prior initialization or limitations to the values of $R_{s}$ and $R_{s h}$.

86

87 2. Methodology

88 The equation of single-diode model (SDM) used to simulate the $I$ - $V$ characteristic of solar cells

89 is given by:

$90 \quad I=I_{p h}-I_{o}\left[\exp \left(\frac{V+I R_{s}}{a V_{t}}\right)-1\right]-\frac{\left(V+I R_{s}\right)}{R_{s h}}$

where $a$ is the ideality factor of the solar cell, $I_{o}$ is the saturation current in dark condition and

$V_{t}$ is the thermal voltage $\left(k_{B} T / q\right)$. The $k_{B}$ is Boltzmann's constant, $T$ is the cell's temperature

in Kelvin, $q$ is the elementary charge, while $R_{s}$ and $R_{s h}$ are the series and shunt resistance,

respectively. Because PV module is composed of $N_{s}$ series connected cells, the value of $a$ in

95 Equation 1 is replaced by $n=N_{s} \times a$ in the subsequent mathematical operations.

96 Based on the characteristic curve of solar cells, it is possible to derive three formulas from

97 Equation 1, considering the boundary conditions at open circuit voltage $\left(V_{o c}\right)$, short circuit

98 current $\left(I_{s c}\right)$ and maximum power $\left(P_{m}\right)$ as follows, respectively:

$0=I_{p h}+I_{o}-I_{o} \exp \left(\frac{V_{o c}}{n V_{t}}\right)-\frac{V_{o c}}{R_{s h}}$

100

$I_{s c}=I_{p h}+I_{o}-I_{o} \exp \left(\frac{R_{s} I_{s c}}{n V_{t}}\right)-\frac{R_{s} I_{s c}}{R_{s h}}$

$101 I_{m}=I_{p h}+I_{o}-I_{o} \exp \left(\frac{R_{s} I_{m}+V_{m}}{n V_{t}}\right)-\frac{R_{s} I_{m}}{R_{s h}}-\frac{V_{m}}{R_{s h}}$

102 Subtracting Equation 2 from 3 and solving for the saturation current $\left(I_{o}\right)$, one can get:

103

$$
I_{o}=\frac{I_{s c}-\frac{V_{o c}}{R_{s h}}+\frac{R_{s}}{R_{s h}} I_{s c}}{\exp \left(\frac{V_{o c}}{n V_{t}}\right)-\exp \left(\frac{R_{S} I_{S c}}{n V_{t}}\right)} .
$$


104 A safe approximation is to neglect $\exp \left(\frac{R_{s} I_{s c}}{n V_{t}}\right)$ due to its very small value $[48,31,49,50]$. Hence,

105 Equation 3 and 5 can be respectively reduced to:

$106 \quad I_{p h}=I_{s c}-I_{o}+\frac{R_{s} I_{s c}}{R_{s h}}$

107

$I_{o}=\frac{I_{s c}-\frac{V_{o c}}{R_{s h}}+\frac{R_{s}}{R_{s h}} I_{s c}}{\exp \left(\frac{V_{o c}}{n V_{t}}\right)}$

108 It is known that when the internal impedance $\left(Z_{i n}\right)$ of the solar cell is equal to the impedance of

109 the external load $\left(Z_{\text {out }}\right)$, maximum power $\left(P_{m}\right)$ is delivered, that is where:

$110 \quad Z_{\text {in }}=Z_{\text {out }}=\frac{V_{m}}{I_{m}}$

111 Moreover, from the single-diode model, the impedance function can be represented by:

$112 \frac{R_{s h} r_{d}}{R_{s h}+r_{d}}+R_{s}=\frac{V_{m}}{I_{m}}$

113 Where $r_{d}$ is the dynamic resistance of the diode at $P_{\max }$, which can be determined from the first

114 derivative of the diode voltage with respect to its current as follows:

$115 \quad r_{d}=\left.\frac{d V_{D}}{d I_{D}}\right|_{P_{m}}=\frac{n V_{t}}{I_{o} \exp \left(\frac{R_{S} I_{m}+V_{m}}{n V_{t}}\right)}$

116 Substituting Equation 10 into 9 and performing some mathematical manipulations, it yields:

$I_{o} \exp \left(\frac{R_{s} I_{m}+V_{m}}{n V_{t}}\right)=\frac{n V_{t}\left(I_{m}-\frac{V_{m}}{R_{s h}}+\frac{R_{s} I_{m}}{R_{s h}}\right)}{V_{m}-R_{s} I_{m}} \ldots \ldots \ldots \ldots$

118 Furthermore, by subtracting Equation 2 from 4 and inserting Equation 7 one can achieve:

$119 I_{o} \exp \left(\frac{R_{s} I_{m}+V_{m}}{n V_{t}}\right)=I_{s c}-I_{m}+\frac{R_{s}}{R_{s h}}\left(I_{s c}-I_{m}\right)-\frac{V_{m}}{R_{s h}}$

120 Now, from Equation 11 and 12 an explicit formula for $R_{s h}$ is obtained:

$121 \quad R_{s h}=\frac{V_{m}^{2}+R_{s}^{2}\left(I_{s c} I_{m}-I_{m}^{2}\right)+R_{s}\left(n V_{t} I_{m}-I_{s c} V_{m}\right)-n V_{t} V_{m}}{R_{s}\left(I_{m}^{2}-I_{s c} I_{m}\right)+V_{m}\left(I_{s c}-I_{m}\right)-n V_{t} I_{m}}$

122 Another explicit form of $R_{s h}$ can be derived from Equation 6 and 4 to achieve:

$123 \quad I_{p h}+I_{o}=I_{s c}+\frac{R_{s} I_{s c}}{R_{s h}}=I_{m}+I_{o} \exp \left(\frac{R_{s} I_{m}+V_{m}}{n V_{t}}\right)+\frac{R_{s} I_{m}}{R_{s h}}+\frac{V_{m}}{R_{s h}} \ldots \ldots \ldots \ldots$ 
124 By substituting Equation 7 into Equation 14 and solving for $R_{s h}$, one can get:

$125 \quad R_{s h}=\frac{R_{s} I_{s c} A-V_{o c} A-R_{s} I_{s c}+R_{s} I_{m}+V_{m}}{I_{s c}-I_{m}-I_{s c} A}$

126 where $A=\exp \left(\frac{R_{s} I_{m}+V_{m}-V_{o c}}{n V_{t}}\right)$.

127 Now, by equating Equation 13 and 15, an implicit form of $R_{s}$ can be derived, which is:

$R_{s}=\frac{V_{o c} V_{m}\left(I_{s c}-I_{m}\right)+n V_{t}\left(I_{s c} V_{m}-I_{m} V_{o c}\right)-V_{m}^{2} I_{s c}+\frac{n V_{t} V_{m}\left(2 I_{m}-I_{s c}\right)}{A}}{I_{s c} I_{m}\left(V_{o c}-V_{m}\right)-I_{m}^{2} V_{o c}}$

129 From Equation 13 and 16, it is obvious that the value of $R_{s}$ and $R_{s h}$ can be efficiently determined

130 if and only if the ideality factor is accurately identified. A review of literature showed that it is

131 hard to find the accurate value of ideality factor as its value is highly dependent on the parasitic resistances [51,52]. Hence, researchers utilized some approximate equations to determine the value of ideality factor [53-57]. This is ultimately led to inaccurate extraction of the other

134 parameters due to their dependence on the ideality factor. Therefore, in the current work, the

135 value of ideality factor is iterating in fine steps in order to determine the five parameters as accurate as possible, following the detailed procedure which is given in the next subsection.

It is worth to mention that the proposed technique utilizes the main datasheet information provided by the manufacturer, as shown in Table 1 . The accuracy and robustness of the proposed method is validated on four different technologies of PV modules, namely monocrystalline, poly-crystalline, thin film and hybrid/multilayer. One can see that there are three unknown parameters to be determined from Equation 13 and 16, namely $n, R_{s}$ and $R_{s h}$.

142 Therefore, the target is to reduce them to two unknown parameters. This is realized by iterating

143 the value of $n$ in Equation 16 and 13 respectively to determine $R_{s}$ (using fzero function in

144 MATLAB) and $R_{s h}$. Later on, the values of $I_{p h}$ and $I_{o}$ can be extracted at the accurate value of $145 n$ using Equation 6 and 7, respectively.

147 Table 1. The utilized datasheet information provided by the manufacturer at STC. 


\begin{tabular}{llll}
\hline PV module (Type) & SM55 (Mono-Si) & KC200GT (Poly-Si) & ST40 (Thin film) \\
\hline $\boldsymbol{V}_{\boldsymbol{m}}(\mathbf{V})$ & 17.4 & 26.3 & 16.6 \\
$\boldsymbol{I}_{\boldsymbol{m}}(\mathbf{A})$ & 3.15 & 7.61 & 2.41 \\
$\boldsymbol{V}_{\boldsymbol{~} \boldsymbol{c}}(\mathbf{V})$ & 21.7 & 32.9 & 23.3 \\
$\boldsymbol{I}_{\boldsymbol{s}}(\mathbf{A})$ & 3.45 & 8.21 & 2.68 \\
$\boldsymbol{N}_{\text {cell }}$ & 36 & 54 & 36 \\
\hline
\end{tabular}

149 An interesting correlation was observed between $R_{s h}$ and $n$ (see Figure 1), from which an 150 empirical formula was derived and used to determine the value of ideality factor and shunt 151 resistance as follows:

$$
f\left(n, R_{\text {sh }}\right)=n\left(R_{\text {sh_max }}-R_{\text {sh }}\right)
$$

153 Where $R_{s h \_ \text {max }}$ is the maximum positive value of shunt resistance over the iterated interval of

154 the ideality factor, where $0<R_{\text {sh }} \leq R_{\text {shmax }}$ is held. It has been found that at the knee point 155 on the curve of $R_{s h}$ versus $n$, i.e. at the peak value of $f\left(n, R_{s h}\right)$, as shown in Figure 1 for the 156 representative SM55 PV module, minimum relative error was obtained between the datasheet 157 and calculated currents. Therefore, the values of $n$ and $R_{s h}$ are first extracted at the peak of $158 f\left(n, R_{s h}\right)$ and then they are used to determine the other parameters. The implementation steps 159 of the proposed technique are shown in Figure 2.

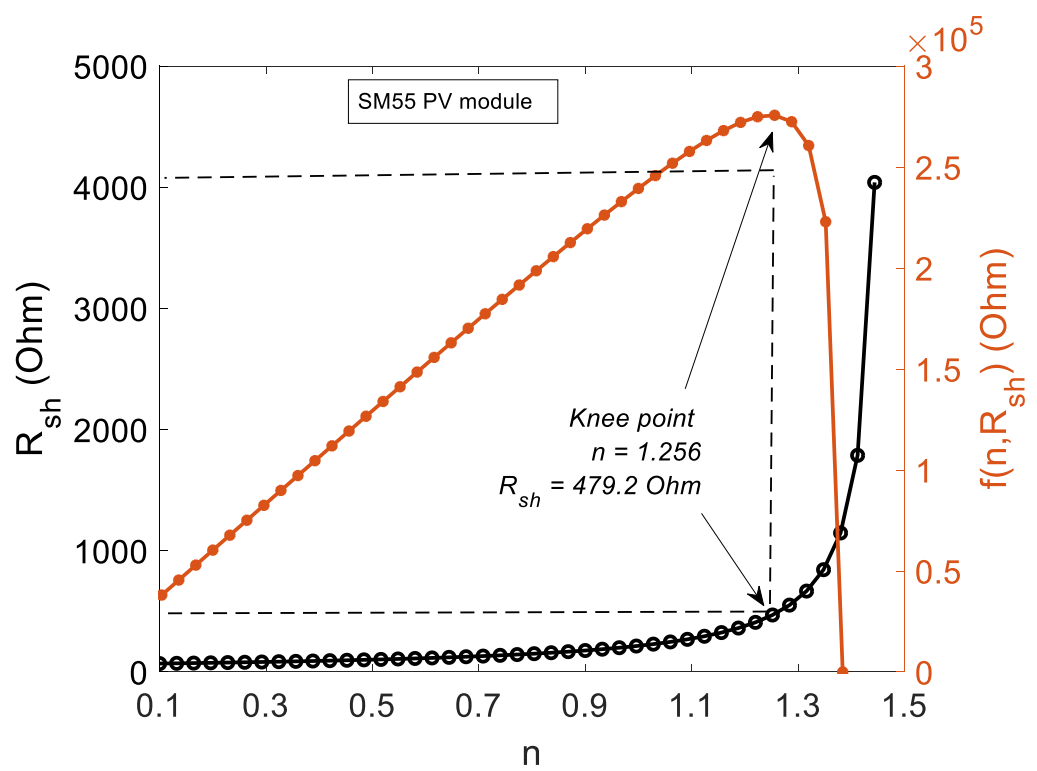

160

Figure 1. Plot of $R_{s h}$ versus $n$ and $f\left(n, R_{s h}\right)$ for the representative SM55 PV module. 


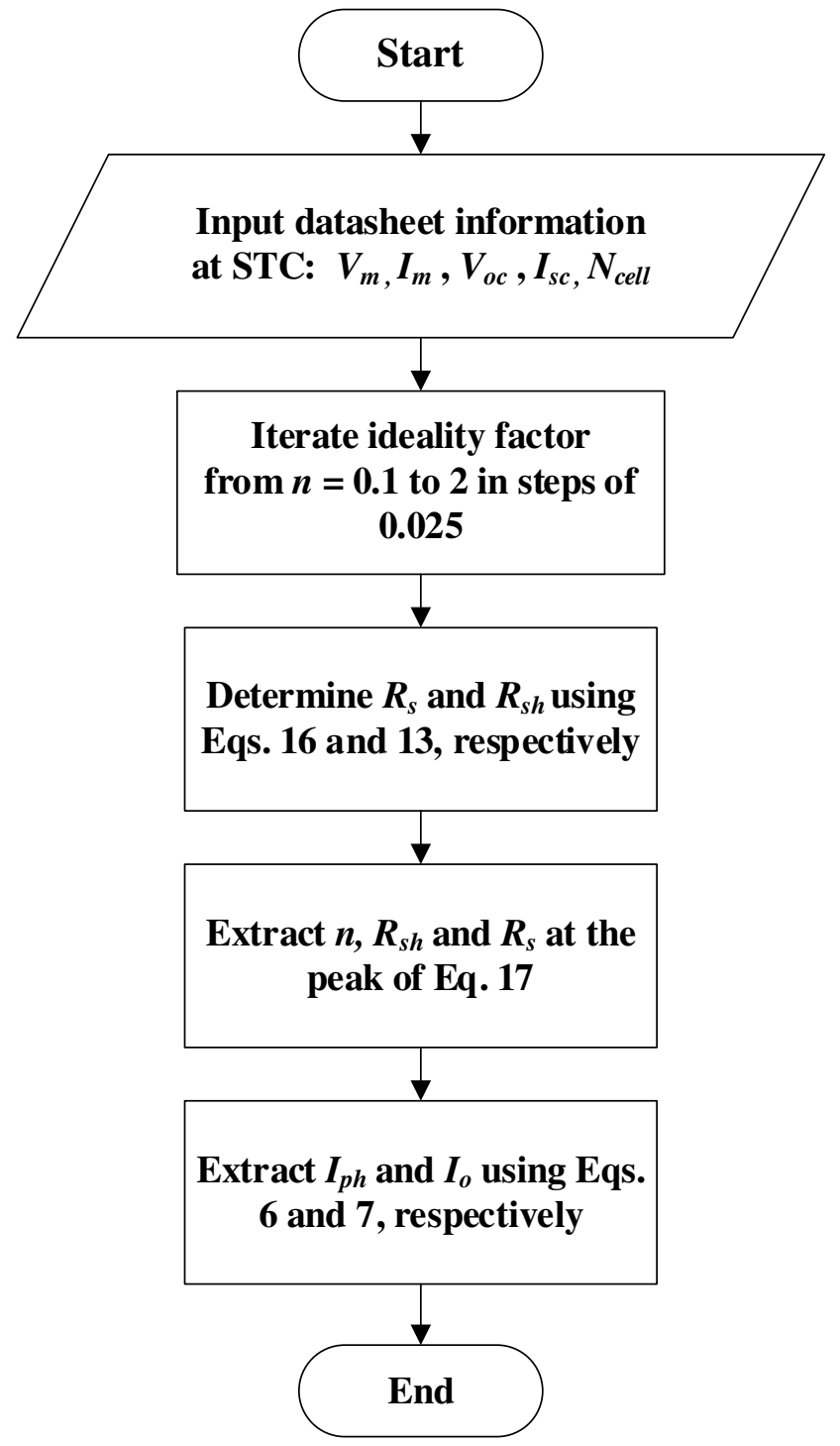

163 Figure 2. Flowchart of the proposed method to compute the parameters of PV modules.

\section{Results and Discussion}

166 Validation of the proposed method was first performed by extracting the parameters of three

167 PV modules, namely mono-Si (SM55), poly-Si (KC200GT) and thin film (ST40), while the

168 obtained results were compared to that of the datasheet information and those reported in

169 literature using different techniques. By considering the datasheet information shown in Table

1701 for each of the modules and a simple iteration of ideality factor, the electrical parameters

171 were determined, as shown in Table 2. 
173 Table 2. Computed parameters using the proposed iterative technique at STC.

\begin{tabular}{llll}
\hline PV module (Type) & SM55 (Mono-Si) & KC200GT (Poly-Si) & ST40 (Thin film) \\
$\boldsymbol{n}$ & 1.256 & 1.192 & 1.992 \\
$\boldsymbol{R}_{\boldsymbol{s}}(\boldsymbol{\Omega})$ & 0.381 & 0.212 & 0.899 \\
$\boldsymbol{R}_{\boldsymbol{s} \boldsymbol{h}}(\boldsymbol{\Omega})$ & 479.2 & 388.6 & 278.2 \\
$\boldsymbol{I}_{\boldsymbol{o}}(\mathbf{A})$ & $2.816 \mathrm{E}-8$ & $1.675 \mathrm{E}-8$ & $6.519 \mathrm{E}-6$ \\
$\boldsymbol{I}_{\boldsymbol{p h}}(\mathbf{A})$ & 3.453 & 8.184 & 2.687 \\
Relative error & $1.040 \%$ & $1.87 \%$ & $2.66 \%$ \\
\hline
\end{tabular}

174

175 Consequently, the calculated parameters were employed to simulate the $I$ - $V$ characteristics for

176 each technology. Later on, the $I-V$ curves were compared to that extracted from the

177 manufacturer datasheet $[5,58]$ and those reported in literature by iterative methods under the

178 changes of irradiance and temperature $[47,59,19,46]$. In order to quantitatively investigate the

179 accuracy of the proposed technique, the maximum relative errors between calculated and

180 manufacturer currents were determined and compared to those achieved by other researchers

181 for the PV modules under different irradiance levels, as shown in Table 3. One can notice from

182 the results that the proposed method has performed very well for both mono- and poly-Si PV

183 modules at low and high irradiance levels. Generally, the calculated results well matched with

184 the datasheet results and outperformed those reported in literature for all types of the PV

185 modules, as shown in Figure 2 and Table 3. However, it was somehow weak against the thin

186 film-based PV module (ST40). Comparably, the parameters determined from the methods

187 proposed by El Achouby et al. and Zaimi et al. [19,59] were found not to be applicable for thin

188 film PV modules due to large errors, while they are more accurate for the mono- and poly-Si

189 technologies.

190

191

192

193 
194 Table 3. Maximum relative error of the proposed method and those reported in literature 195 applied on different PV technologies at temperature $25^{\circ} \mathrm{C}$ and varied irradiance.

196

\begin{tabular}{llll}
\hline PV module (Type) & Irradiance $\left(\mathbf{W} / \mathbf{m}^{2}\right)$ & This work & Chaibi et al. [47] \\
\hline & 200 & $\mathbf{1 . 7 1 \%}$ & $2.38 \%$ \\
& 400 & $4.94 \%$ & $\mathbf{2 . 3 1 \%}$ \\
SM55 (Mono-Si) & 600 & $\mathbf{1 . 7 1 \%}$ & $2.02 \%$ \\
& 800 & $\mathbf{0 . 4 4 \%}$ & $0.89 \%$ \\
& 1000 & $\mathbf{1 . 0 4 \%}$ & $1.41 \%$ \\
\hline \multirow{5}{*}{ KC200GT (Poly-Si) } & 200 & $\mathbf{3 . 9 7 \%}$ & $4.38 \%$ \\
& 400 & $5.01 \%$ & $\mathbf{4 . 0 3 \%}$ \\
& 600 & $\mathbf{3 . 9 3 \%}$ & $4.19 \%$ \\
& 800 & $\mathbf{1 . 8 2 \%}$ & $2.38 \%$ \\
ST40 (Thin film) & 1000 & $\mathbf{1 . 8 7 \%}$ & $2.19 \%$ \\
& 200 & $\mathbf{2 . 0 1 \%}$ & $2.40 \%$ \\
& 400 & $1.24 \%$ & $\mathbf{0 . 9 8 \%}$ \\
& 600 & $3.01 \%$ & $1.05 \%$ \\
& 800 & $\mathbf{1 . 8 6 \%}$ & $2.13 \%$ \\
& 1000 & $\mathbf{1 . 6 6 \%}$ & $1.73 \%$ \\
\hline
\end{tabular}

197

198

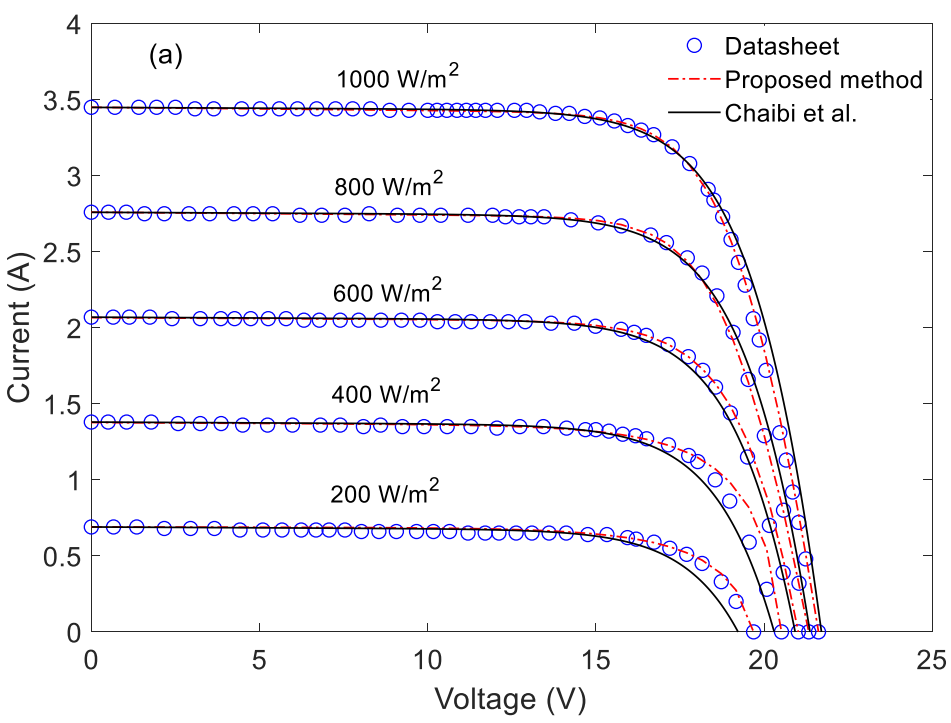

199

Voltage $(\mathrm{V})$ 


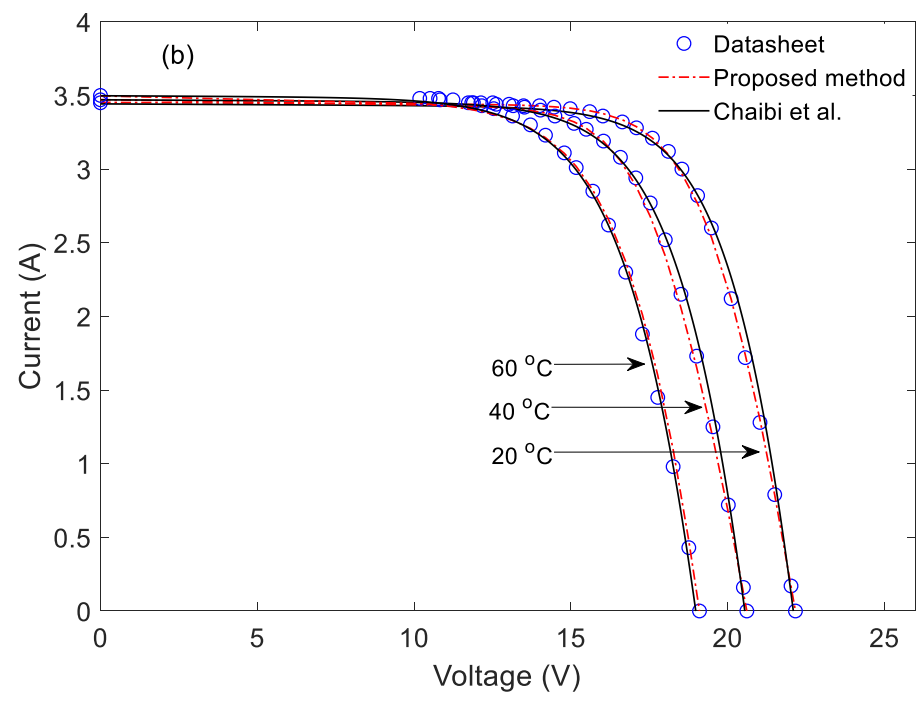

202 Figure 2. The datasheet and simulated $I$ - $V$ curves of the SM55 PV module under (a) uniform 203 change of irradiance and fixed $T=25^{\circ} \mathrm{C}$, and (b) uniform change of temperature and $\mathrm{G}=$ $1000 \mathrm{~W} / \mathrm{m}^{2}$.

206 Figure 3 and 4 show the simulated $I$ - $V$ curves for KC200GT and ST40 PV modules that were 207 produced from the parameter's estimation by the proposed approach, the method of Chaibi's 208 et al. and datasheet based $I-V$. It can be seen that the proposed iterative method is well fitting 209 the measured data at varied irradiance and temperature. Noteworthy, there has been less 210 deviation of the calculated curves from those of the measured ones at low temperatures and 211 high irradiances, implying efficient response of the proposed method compared to those 212 reported in literature. 

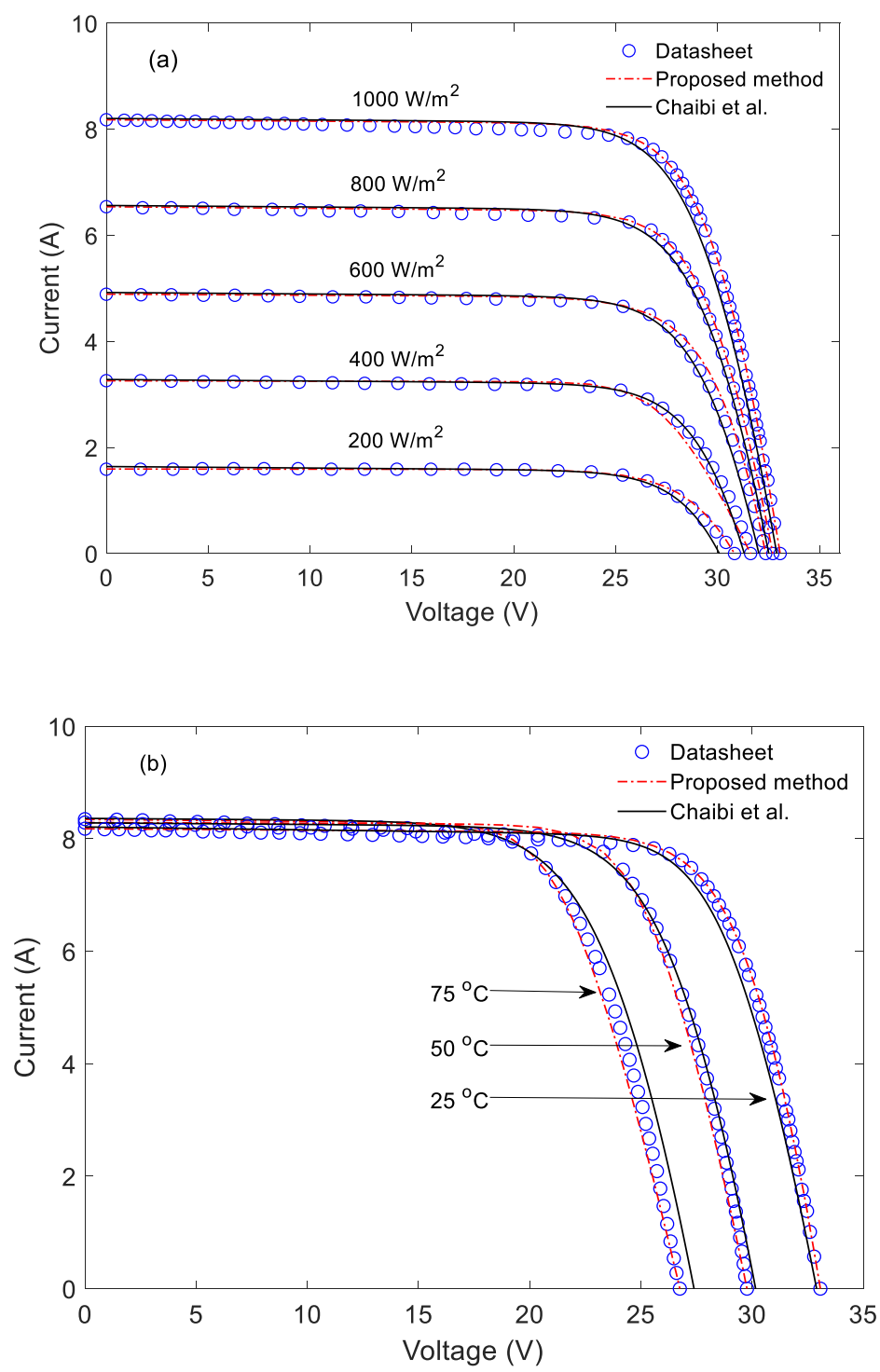

Figure 3. The datasheet and simulated $I$ - $V$ curves of the KC200GT PV module under (a)

216 uniform change of irradiance and fixed $T=25^{\circ} \mathrm{C}$, and (b) uniform change of temperature and

$$
\mathrm{G}=1000 \mathrm{~W} / \mathrm{m}^{2} \text {. }
$$



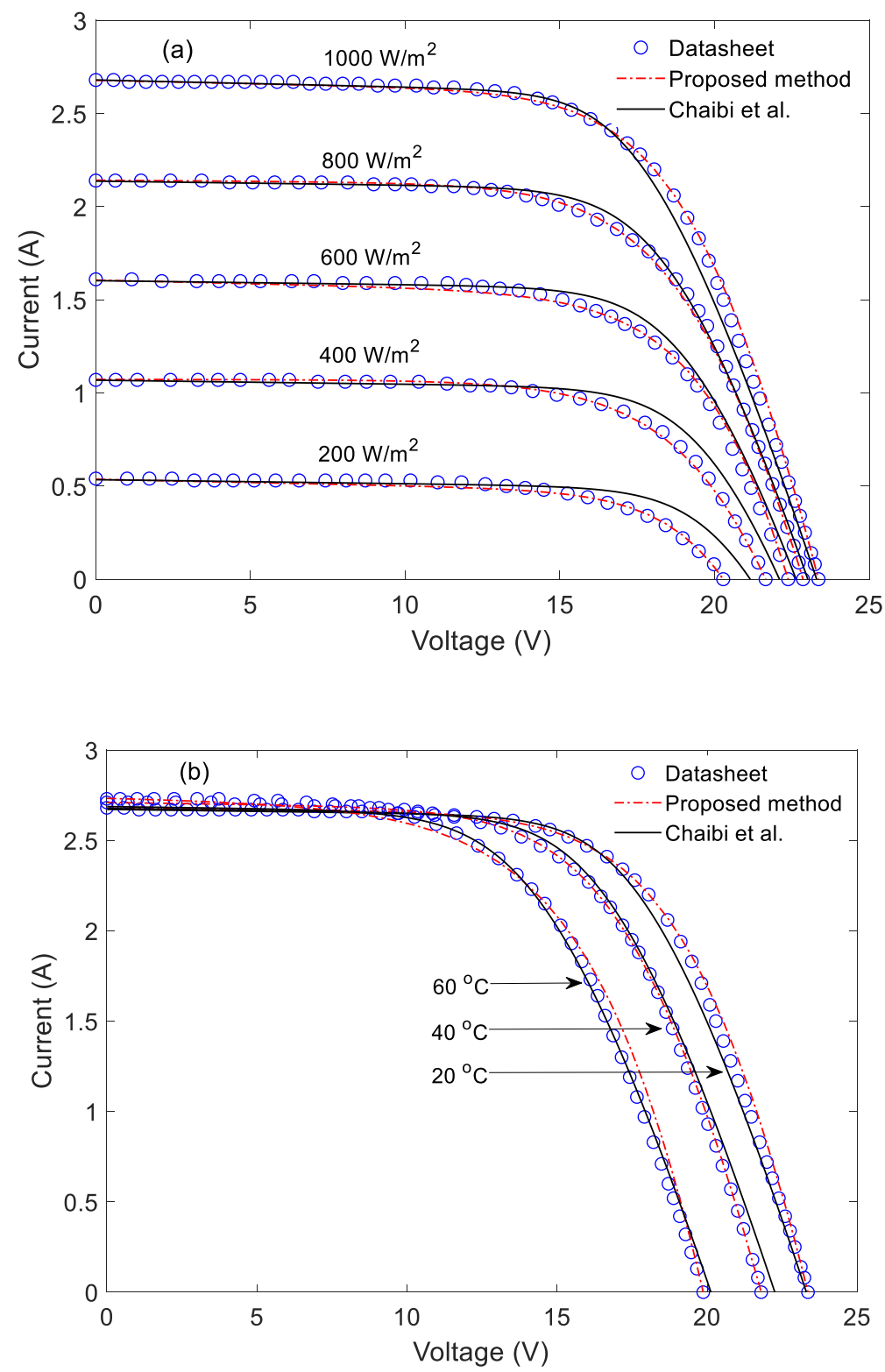

Figure 4. The datasheet and simulated $I$ - $V$ curves of the ST40 PV module under (a) uniform change of irradiance and fixed $T=25{ }^{\circ} \mathrm{C}$, and (b) uniform change of temperature and $\mathrm{G}=$ $1000 \mathrm{~W} / \mathrm{m}^{2}$.

225 Table 4 shows the maximum relative error between the datasheet and proposed method for 226 different PV technologies at irradiance $100 \mathrm{~W} / \mathrm{m}^{2}$ and varied temperature. Compared to the 227 other methods, it is noticeable that the proposed method is performing better in the low temperature range of PV modules. However, at high temperatures the Chaibi's et al. method is 
more efficient. Interestingly, the proposed approach has performed well for thin film PV technology even at relatively high temperatures of about $50{ }^{\circ} \mathrm{C}$.

231

232

233

235

236

237

238

239 and efficiently by using the datasheet information.

Table 4. Maximum relative error of the proposed method and those reported in literature applied on different PV technologies at irradiance $100 \mathrm{~W} / \mathrm{m}^{2}$ and varied temperature.

\begin{tabular}{llll}
\hline PV module (Type) & Temperature $\left({ }^{\mathbf{0}} \mathbf{C}\right)$ & This work & Chaibi et al. [47] \\
\hline \multirow{2}{*}{ SM55 (Mono-Si) } & 20 & $\mathbf{0 . 6 4 \%}$ & $1.02 \%$ \\
& 40 & $\mathbf{0 . 7 6 \%}$ & $0.78 \%$ \\
& 60 & $2.75 \%$ & $\mathbf{0 . 6 2 \%}$ \\
\hline \multirow{2}{*}{ KC200GT (Poly-Si) } & 20 & $\mathbf{1 . 8 7 \%}$ & $2.19 \%$ \\
& 60 & $2.60 \%$ & $\mathbf{1 . 2 4 \%}$ \\
& 60 & $\mathbf{1 . 0 2 \%}$ & $1.90 \%$ \\
\multirow{2}{*}{ ST40 (Thin film) } & 25 & $3.55 \%$ & $1.44 \%$ \\
& 50 & $\mathbf{1 . 1 4 \%}$ & $1.31 \%$ \\
& 75 & $\mathbf{2 . 1 0 \%}$ & $2.39 \%$ \\
\hline
\end{tabular}

To further validate the proposed method, parameters determination was also performed for a hybrid/multijunction PV module, thin triple-junction CTJ30, which consists of three series cells tested at STC [60]. Table 5 includes the datasheet based $I-V$ data, which was extracted by Origin pro digitalize software, and the calculated currents using the proposed method. As such, the electrical parameters of the PV module were determined to be $n=1.028, R_{s}=0.055 \Omega, R_{s} h$ $=425 \Omega, I_{o}=2.83 \mathrm{E}-15 \mathrm{~A}$ and $I_{p h}=0.473$ A with the relative error of about $2.86 \%$. Figure 5 shows a comparison of the calculated $I-V$ curve to that of the datasheet $I-V$ for the CTJ30 PV module investigated at STC. One can see that the simulation result is very well matched with the measured data, where a small deviation can be noticed along the whole dataset except the MPP at which a relatively increased deviation is noticed. Concludingly, the proposed technique is highly effective to determine the parameters of all types of solar cells and modules easily 
251 Table 5. Determined parameters of CTJ30 PV module at STC using the proposed technique.

\begin{tabular}{|c|c|c|c|}
\hline Voltage (V) & Datasheet current (A) & Calculated current (A) & Absolute error \\
\hline 0.000 & 0.473 & 0.4730 & 0.0000 \\
\hline 0.139 & 0.472 & 0.4728 & 0.0008 \\
\hline 0.297 & 0.472 & 0.4727 & 0.0007 \\
\hline 0.445 & 0.472 & 0.4726 & 0.0006 \\
\hline 0.577 & 0.471 & 0.4724 & 0.0014 \\
\hline 0.722 & 0.471 & 0.4723 & 0.0013 \\
\hline 0.880 & 0.471 & 0.4721 & 0.0011 \\
\hline 1.022 & 0.470 & 0.4720 & 0.0020 \\
\hline 1.189 & 0.470 & 0.4718 & 0.0018 \\
\hline 1.344 & 0.470 & 0.4717 & 0.0017 \\
\hline 1.489 & 0.470 & 0.4715 & 0.0015 \\
\hline 1.640 & 0.469 & 0.4714 & 0.0024 \\
\hline 1.779 & 0.468 & 0.4712 & 0.0032 \\
\hline 1.940 & 0.467 & 0.4708 & 0.0038 \\
\hline 2.078 & 0.465 & 0.4694 & 0.0044 \\
\hline 2.204 & 0.461 & 0.4644 & 0.0034 \\
\hline 2.314 & 0.452 & 0.4487 & 0.0033 \\
\hline 2.385 & 0.428 & 0.4223 & 0.0057 \\
\hline 2.420 & 0.401 & 0.3997 & 0.0013 \\
\hline 2.458 & 0.367 & 0.3637 & 0.0033 \\
\hline 2.484 & 0.332 & 0.3297 & 0.0023 \\
\hline 2.504 & 0.300 & 0.2969 & 0.0031 \\
\hline 2.520 & 0.264 & 0.2658 & 0.0018 \\
\hline 2.539 & 0.227 & 0.2223 & 0.0047 \\
\hline 2.552 & 0.197 & 0.1880 & 0.0090 \\
\hline 2.561 & 0.159 & 0.1618 & 0.0028 \\
\hline 2.574 & 0.122 & 0.1203 & 0.0017 \\
\hline 2.587 & 0.084 & 0.0741 & 0.0099 \\
\hline 2.600 & 0.045 & 0.0229 & 0.0221 \\
\hline \multirow[t]{2}{*}{2.610} & 0.000 & -0.020 & 0.0200 \\
\hline & & Average relative error & $2.86 \%$ \\
\hline
\end{tabular}

252

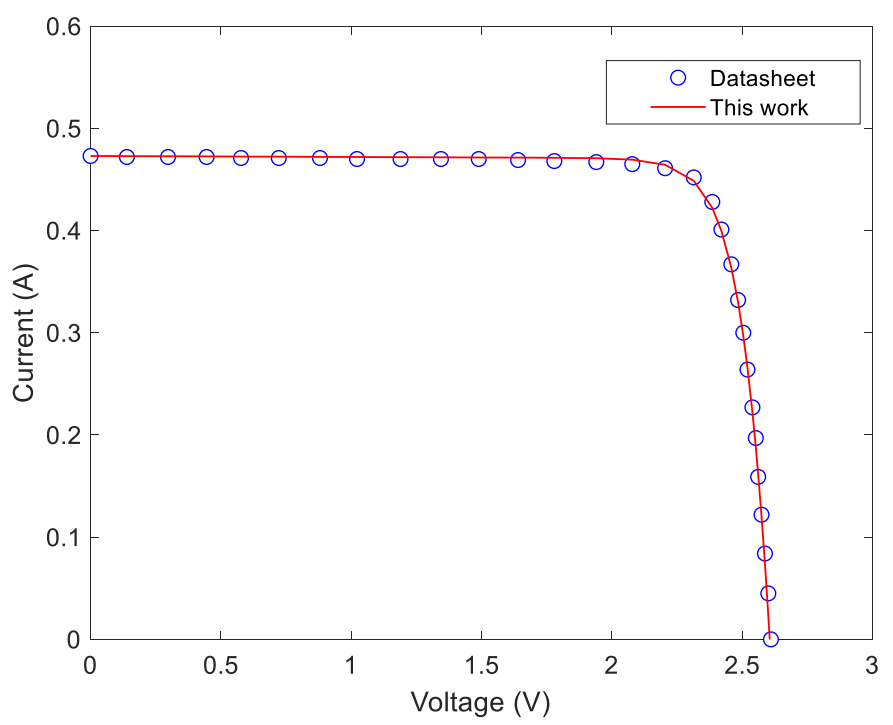

Figure 5. The datasheet and simulated $I-V$ curve of the CTJ30 PV module at STC. 
In comparison to the reported methods in terms of simplicity, a qualitative assessment was performed considering the required datasheet information as input, the initial values to proceed with the iterations and the applicability of the method to various PV technologies. Table 6 shows the analysis of the investigation, where the proposed approach requires only the iteration of ideality factor with respect to the series and shunt resistances. Besides, it uses a simple mathematical approach to determine the value of ideality factor, while most of the other approaches utilize a complex computation or a reduced equation which leads to underestimate the value of $n$. In conclusion, the proposed technique can efficiently and simply determine the parameters at different variations of temperature and irradiance.

Table 6: Comparison of the proposed method with other iterative methods reported in literature.

\begin{tabular}{|l|l|l|l|l|}
\hline Iterative methods & Required data & Initial values & Complexity & Module technology \\
\hline Chaibi et al. [47] & $\begin{array}{l}I_{m}, V_{m}, P_{m}, I_{s c}, V_{o c}, \\
N_{c e l l}, K_{i}, V_{t h}\end{array}$ & $R_{s h 0}$ & Low & Poly-Si, Mono-Si, Thin-film \\
\hline This work & $\begin{array}{l}I_{m}, V_{m}, I_{s c}, V_{o c}, \\
N_{c e l l}, V_{t h}\end{array}$ & $n$ & Very low & Poly-Si, Mono-Si, Thin-film, Hybrid \\
\hline
\end{tabular}

\section{Conclusions}

A simple iterative method was successfully implemented on different PV technologies to determine their parameters from datasheet information only. It has been found that with the help of iterating the ideality factor, it is possible to build a fruitful correlation between $R_{s h}$ and $n$, which has led to derive an empirical formula through which all the parameters were

274 determined at the peak value of the function. It was seen that the proposed method outperformed the other iterative techniques reported in literature, especially at high irradiances and low temperatures which presented a competitive accuracy despite its simplicity. The

277 proposed technique is highly effective to determine the parameters of all types of solar cells and modules easily and efficiently by using the datasheet information. 
$280 \quad$ Funding statement

281 This work did not receive a financial support.

282

283 Conflicts of interest

284 The author declares that there is no conflict of interest regarding the publication of this paper.

285

286 Author contributions

287 Conceptualization, Methodology, Formal analysis and investigation, Writing - original draft 288 preparation, Writing - review and editing: Fahmi F. Muhammadsharif

289

290 Availability of data and material

291 The data and material are available within the manuscript.

292

\section{Compliance with ethical standards}

294 Not applicable

295

296 Consent to participate

297 Not applicable

298

299 Consent for Publication

300 The corresponding author transfers to Springer the non-exclusive publication rights and he 301 warrants that the contribution is original and that he has full power to make this grant. The

302 author signs for and accepts responsibility for releasing this material on behalf of any and all 303 co-authors. This transfer of publication rights covers the non-exclusive right to reproduce and 
304 distribute the article, including reprints, translations, photographic reproductions, microform,

305 electronic form (offline, online) or any other reproductions of similar nature.

306

\section{Acknowledgment}

308 The author should like to thank Assoc. Prof. Dr. Yassine Chaibi at Moroccan School of

309 Engineering Sciences for providing some datasets to validate this work.

\section{$311 \quad$ References}

312 1. McEvoy AJ, Castaner L, Markvart T (2012) Solar cells: materials, manufacture and 313 operation. Academic Press,

314 2. Li Z-S, Zhang G-Q, Li D-M, Zhou J, Li L-J, Li L-X (2007) Application and development of 315 solar energy in building industry and its prospects in China. Energy Policy 35 (8):4121-4127

316 3. Otte K, Makhova L, Braun A, Konovalov I (2006) Flexible Cu (In, Ga) Se 2 thin-film solar 317 cells for space application. Thin Solid Films 511:613-622

318 4. Maouhoub N (2018) Photovoltaic module parameter estimation using an analytical 319 approach and least squares method. Journal of Computational Electronics. 320 doi:10.1007/s10825-017-1121-5

321 5. Chaibi Y, Allouhi A, Malvoni M, Salhi M, Saadani R (2019) Solar irradiance and 322 temperature influence on the photovoltaic cell equivalent-circuit models. Solar Energy 323 188:1102-1110

324 6. Chen Z, Chen Y, Wu L, Cheng S, Lin P, You L (2019) Accurate modeling of photovoltaic 325 modules using a 1-D deep residual network based on IV characteristics. Energy Conversion 326 and Management 186:168187-

327 7. Zhang C, Zhang Y, Su J, Gu T, Yang M (2020) Performance prediction of PV modules 328 based on artificial neural network and explicit analytical model. Journal of Renewable and 329 Sustainable Energy $12(1): 013501$

330 8. Müller B, Hardt L, Armbruster A, Kiefer K, Reise C (2016) Yield predictions for photovoltaic 331 power plants: empirical validation, recent advances and remaining uncertainties. Progress in 332 Photovoltaics: Research and Applications 24 (4):570-583

333 9. Tajuddin M, Arif M, Ayob S, Salam Z (2015) Perturbative methods for maximum power 334 point tracking (MPPT) of photovoltaic (PV) systems: a review. International Journal of Energy 335 Research 39 (9):1153-1178 
336 10. Verma D, Nema S, Shandilya A, Dash SK (2016) Maximum power point tracking (MPPT)

337 techniques: Recapitulation in solar photovoltaic systems. Renewable and Sustainable Energy

338 Reviews 54:1018-1034

339 11. Hu X, Zou Y, Yang Y (2016) Greener plug-in hybrid electric vehicles incorporating 340 renewable energy and rapid system optimization. Energy 111:971-980

341 12. Neubauer C, Samieipour A, Oueslati S, Danilson M, Meissner D (2019) Ageing of 342 kesterite solar cells 1: Degradation processes and their influence on solar cell parameters.

343 Thin Solid Films 669:595-599

344 13. Domanski K, Alharbi EA, Hagfeldt A, Grätzel M, Tress W (2018) Systematic investigation 345 of the impact of operation conditions on the degradation behaviour of perovskite solar cells.

346 Nature Energy $3(1): 61$

347 14. Gaglia AG, Lykoudis S, Argiriou AA, Balaras CA, Dialynas E (2017) Energy efficiency of 348 PV panels under real outdoor conditions-An experimental assessment in Athens, Greece. 349 Renewable energy 101:236-243

350 15. Ahmad Z, Touati F, Muhammad FF, Najeeb MA, Shakoor RA (2017) Effect of ambient 351 temperature on the efficiency of the PCPDTBT: PC71BM BHJ solar cells. Applied Physics A 352123 (7):486. doi:10.1007/s00339-017-1098-8

353 16. Meneses-Rodríguez D, Horley PP, Gonzalez-Hernandez J, Vorobiev YV, Gorley PN 354 (2005) Photovoltaic solar cells performance at elevated temperatures. Solar energy 78 355 (2):243-250

356 17. Muhammad FF, Ketuly KA, Yahya MY (2017) Effect of Thermal Annealing on a Ternary 357 Organic Solar Cell Incorporating Gaq3 Organometallic as a Boosting Acceptor. Journal of 358 Inorganic and Organometallic Polymers and Materials. doi:10.1007/s10904-017-0734-2

359 18. Anani N, Ibrahim H (2020) Adjusting the Single-Diode Model Parameters of a 360 Photovoltaic Module with Irradiance and Temperature. Energies 13 (12):3226

361 19. El Achouby H, Zaimi M, Ibral A, Assaid E (2018) New analytical approach for modelling 362 effects of temperature and irradiance on physical parameters of photovoltaic solar module. 363 Energy Conversion and Management 177:258-271

364 20. Ahmed DR, Mohammed IR, Abdullah HM, Muhammadsharif FF, Sulaiman K, Alsoufi MS, 365 Bawazeer TM (2021) The Correlation of Device Parameters with Illumination Energy to 366 Explore the Performance of a Monocrystalline Silicon Solar Module. Silicon. doi:10.1007/s12633-021-00966-z

368 21. Muhammad FF, Karim Sangawi AW, Hashim S, Ghoshal S, Abdullah IK, Hameed SS 369 (2019) Simple and efficient estimation of photovoltaic cells and modules parameters using 370 approximation and correction technique. PloS one 14 (5):e0216201 
371 22. Muhammadsharif FF, Hashim S, Hameed SS, Ghoshal S, Abdullah IK, Macdonald J,

372 Yahya MY (2019) Brent's algorithm based new computational approach for accurate

373 determination of single-diode model parameters to simulate solar cells and modules. Solar

374 Energy 193:782-798

375 23. Abdulrazzaq AK, Bognár G, Plesz B (2020) Evaluation of different methods for solar 376 cells/modules parameters extraction. Solar Energy 196:183-195

377 24. Chenche LEP, Mendoza OSH, Bandarra Filho EP (2018) Comparison of four methods

378 for parameter estimation of mono-and multi-junction photovoltaic devices using experimental 379 data. Renewable and Sustainable Energy Reviews2838-81:2823

380 25. Waly HM, Azazi HZ, Osheba DS, El-Sabbe AE (2019) Parameters extraction of

381 photovoltaic sources based on experimental data. IET Renewable Power Generation 13

382 (9):1466-1473

383 26. Allouhi A, Saadani R, Buker M, Kousksou T, Jamil A, Rahmoune M (2019) Energetic, 384 economic and environmental (3E) analyses and LCOE estimation of three technologies of PV 385 grid-connected systems under different climates. Solar Energy 178:25-36

386 27. Senturk A, Eke R (2017) A new method to simulate photovoltaic performance of 387 crystalline silicon photovoltaic modules based on datasheet values. Renewable energy 388 103:58-69

389 28. Yıldıran N, Tacer E (2016) Identification of photovoltaic cell single diode discrete model 390 parameters based on datasheet values. Solar Energy 127183-175:

391 29. Muhammad FF, Yahya MY, Hameed SS, Aziz F, Sulaiman K, Rasheed MA, Ahmad Z 392 (2017) Employment of single-diode model to elucidate the variations in photovoltaic 393 parameters under different electrical and thermal conditions. PLoS ONE 12 (8):e0182925

394 30. Orioli A, Di Gangi A (2016) A criterion for rating the usability and accuracy of the one395 diode models for photovoltaic modules. Energies 9 (6):427

396 31. Cubas J, Pindado S, de Manuel C (2014) Explicit expressions for solar panel equivalent 397 circuit parameters based on analytical formulation and the Lambert W-function. Energies 7 398 (7):4098-4115

399 32. Pindado S, Cubas J (2017) Simple mathematical approach to solar cell/panel behavior 400 based on datasheet information. Renewable energy 103:729-738

401 33. Gong W, Cai Z (2013) Parameter extraction of solar cell models using repaired adaptive 402 differential evolution. Solar Energy 94:209-220

403 34. Ishaque K, Salam Z (2011) An improved modeling method to determine the model 404 parameters of photovoltaic (PV) modules using differential evolution (DE). Solar Energy 85 405 (9):2349-2359 
406 35. Askarzadeh A, Rezazadeh A (2013) A new heuristic optimization algorithm for modeling

407 of proton exchange membrane fuel cell: bird mating optimizer. International Journal of Energy

408 Research1204-1196:(10) 37

409 36. Askarzadeh A, Rezazadeh A (2013) Extraction of maximum power point in solar cells

410 using bird mating optimizer-based parameters identification approach. Solar energy 90:123-

$411 \quad 133$

412 37. Askarzadeh A, dos Santos Coelho L (2015) Determination of photovoltaic modules

413 parameters at different operating conditions using a novel bird mating optimizer approach.

414 Energy Conversion and Management 89:608-614

415 38. Jervase JA, Bourdoucen H, Al-Lawati A (2001) Solar cell parameter extraction using 416 genetic algorithms. Measurement Science and Technology 12 (11):1922

417 39. Zagrouba M, Sellami A, Bouaïcha M, Ksouri M (2010) Identification of PV solar cells and 418 modules parameters using the genetic algorithms: Application to maximum power extraction.

419 Solar energy $84(5): 860-866$

420 40. Oliva D, Cuevas E, Pajares G (2014) Parameter identification of solar cells using artificial 421 bee colony optimization. Energy 72:93-102

422 41. Ye M, Wang X, Xu Y (2009) Parameter extraction of solar cells using particle swarm 423 optimization. Journal of Applied Physics 105 (9):094502

424 42. Yeh W-C (2009) A two-stage discrete particle swarm optimization for the problem of 425 multiple multi-level redundancy allocation in series systems. Expert Systems with Applications $42636(5): 9192-9200$

427 43. Yousri $D$, Rezk H, Fathy A (2020) Identifying the parameters of different configurations 428 of photovoltaic models based on recent artificial ecosystem-based optimization approach. 429 International Journal of Energy Research

430 44. Zhang $Y$, Ma M, Jin Z (2020) Backtracking search algorithm with competitive learning for 431 identification of unknown parameters of photovoltaic systems. Expert Systems with 432 Applications 160:113750

433 45. Sera D, Teodorescu R, Rodriguez P PV panel model based on datasheet values. In: 2007 434 IEEE international symposium on industrial electronics, 2007. IEEE, pp 2392-2396

435 46. Villalva MG, Gazoli JR, Ruppert Filho E (2009) Comprehensive approach to modeling 436 and simulation of photovoltaic arrays. IEEE Transactions on power electronics 24 (5):1198$437 \quad 1208$

438 47. Chaibi Y, Allouhi A, Salhi M (2020) A simple iterative method to determine the electrical 439 parameters of photovoltaic cell. Journal of Cleaner Production:122363 
440 48. Lineykin S, Averbukh M, Kuperman A (2014) An improved approach to extract the singlediode equivalent circuit parameters of a photovoltaic cell/panel. Renewable and Sustainable

442 Energy Reviews 30:282-289

443 49. Zhang C, Zhang J, Hao Y, Lin Z, Zhu C (2011) A simple and efficient solar cell parameter 444 extraction method from a single current-voltage curve. Journal of applied physics 110 445 (6):064504

446 50. Tong NT, Pora W (2016) A parameter extraction technique exploiting intrinsic properties 447 of solar cells. Applied energy 176:104-115

448 51. da Luz CMA, Tofoli FL, dos Santos Vicente P, Vicente EM (2018) Assessment of the 449 ideality factor on the performance of photovoltaic modules. Energy Conversion and 450 Management 167:63-69

451 52. Yordanov GH, Midtgård O-M, Saetre TO Ideality factor behavior between the maximum 452 power point and open circuit. In: 2013 IEEE 39th Photovoltaic Specialists Conference (PVSC), 453 2013. IEEE, pp 0729-0733

454 53. Maouhoub N (2018) Photovoltaic module parameter estimation using an analytical approach and least squares method. Journal of Computational Electronics:1-7

456 54. Ulapane NN ,Dhanapala $\mathrm{CH}$, Wickramasinghe SM, Abeyratne SG, Rathnayake N, 457 Binduhewa PJ Extraction of parameters for simulating photovoltaic panels. In: 2011 6th 458 International Conference on Industrial and Information Systems, 2011. IEEE, pp 539-544

459 55. Shinong W, Qianlong M, Jie X, Yuan G, Shilin L (2020) An improved mathematical model 460 of photovoltaic cells based on datasheet information. Solar Energy 199:437-446

461 56. Cuce E, Cuce PM, Karakas IH, Bali T (2017) An accurate model for photovoltaic (PV) 462 modules to determine electrical characteristics and thermodynamic performance parameters.

463 Energy Conversion and Management 146:205-216

464 57. Gulkowski S, Diez JVM, Tejero JA, Nofuentes G (2019) Computational modeling and 465 experimental analysis of heterojunction with intrinsic thin-layer photovoltaic module under 466 different environmental conditions. Energy 172:380-390

467 58. Chaibi Y, Malvoni M, Allouhi A, Mohamed S (2019) Data on the I-V characteristics related 468 to the SM55 monocrystalline PV module at various solar irradiance and temperatures. Data in 469 brief 26

470 59. Zaimi M, El Achouby H, Ibral A, Assaid E (2019) Determining combined effects of solar 471 radiation and panel junction temperature on all model-parameters to forecast peak power and 472 photovoltaic yield of solar panel under non-standard conditions. Solar Energy 191:341-359 473 60. CESI (2020) Thin Triple-Junction Solar Cell for Space Applications (CTJ30 - Thin). 474 https://www.cesi.it/app/uploads/2020/03/Datasheet-CTJ30-Thin.pdf . 
Figures

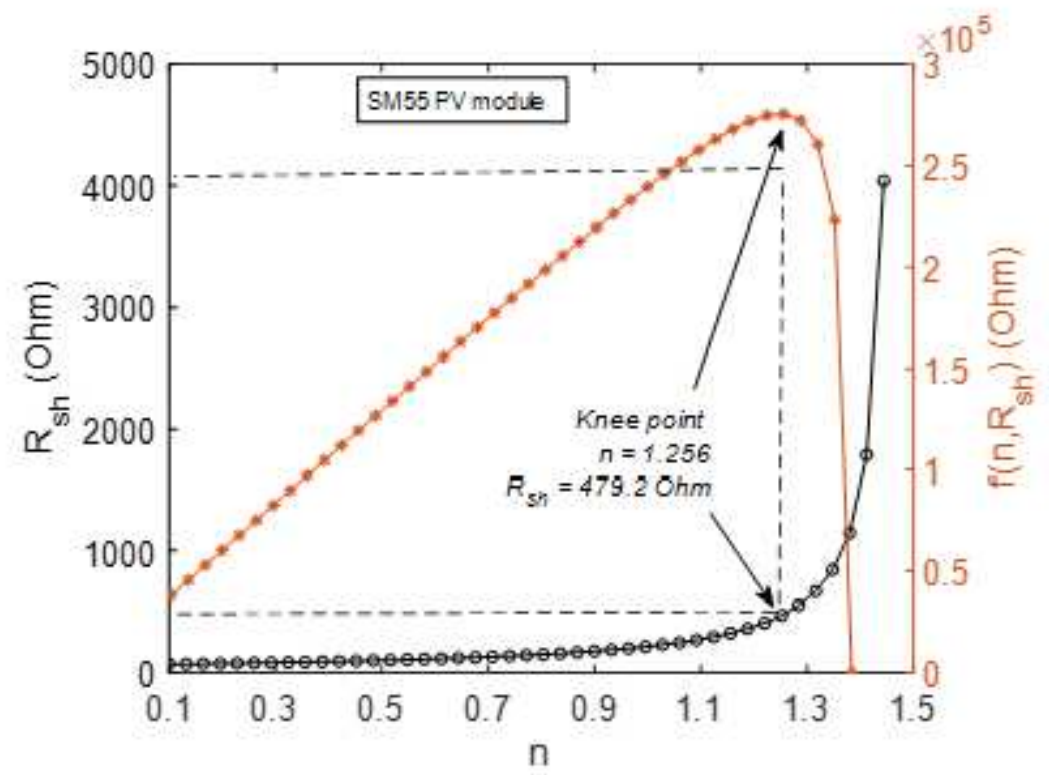

Figure 1

Plot of Rsh versus $n$ and $f(n, R s h)$ for the representative SM55 PV module. 


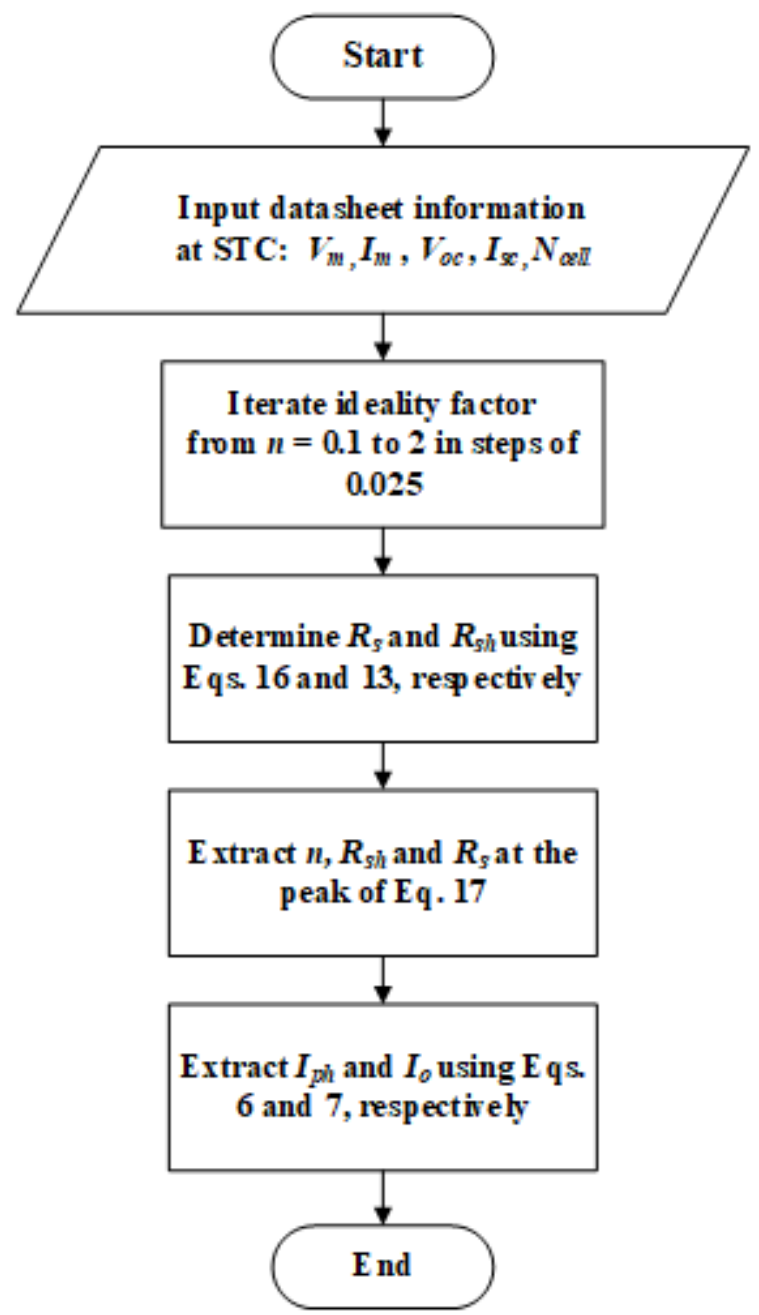

Figure 2

Flowchart of the proposed method to compute the parameters of PV modules. 

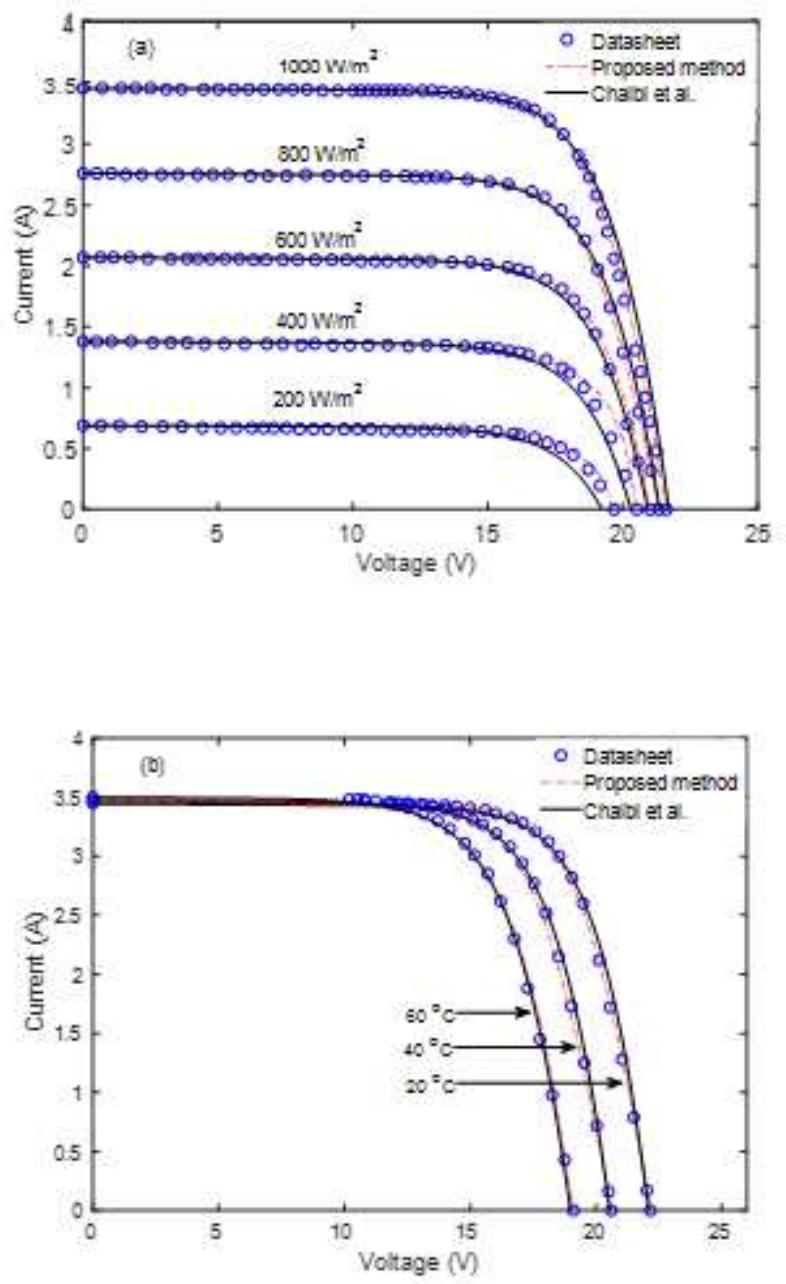

Figure 3

The datasheet and simulated I-V curves of the SM55 PV module under (a) uniform change of irradiance and fixed $T=25 \mathrm{oC}$, and (b) uniform change of temperature and $\mathrm{G}=1000 \mathrm{~W} / \mathrm{m} 2$. 

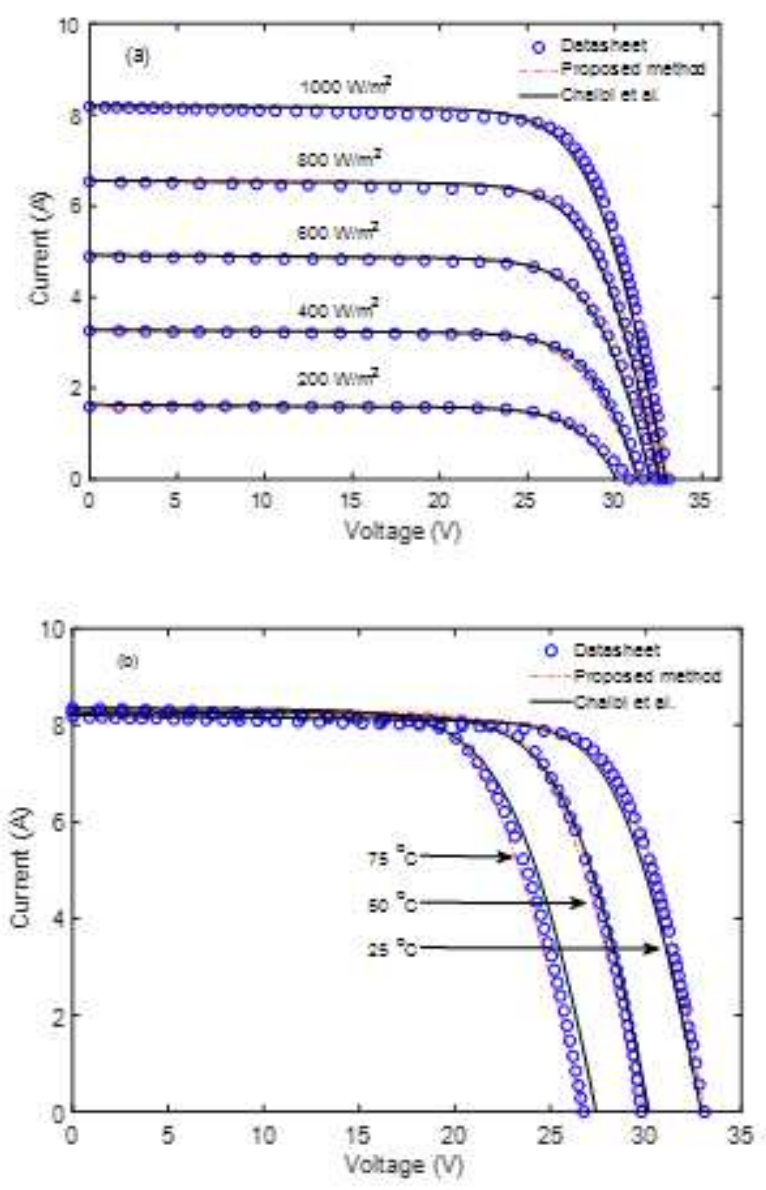

Figure 4

The datasheet and simulated I-V curves of the KC200GT PV module under (a) uniform change of irradiance and fixed $\mathrm{T}=25 \mathrm{oC}$, and (b) uniform change of temperature and $\mathrm{G}=1000 \mathrm{~W} / \mathrm{m} 2$. 

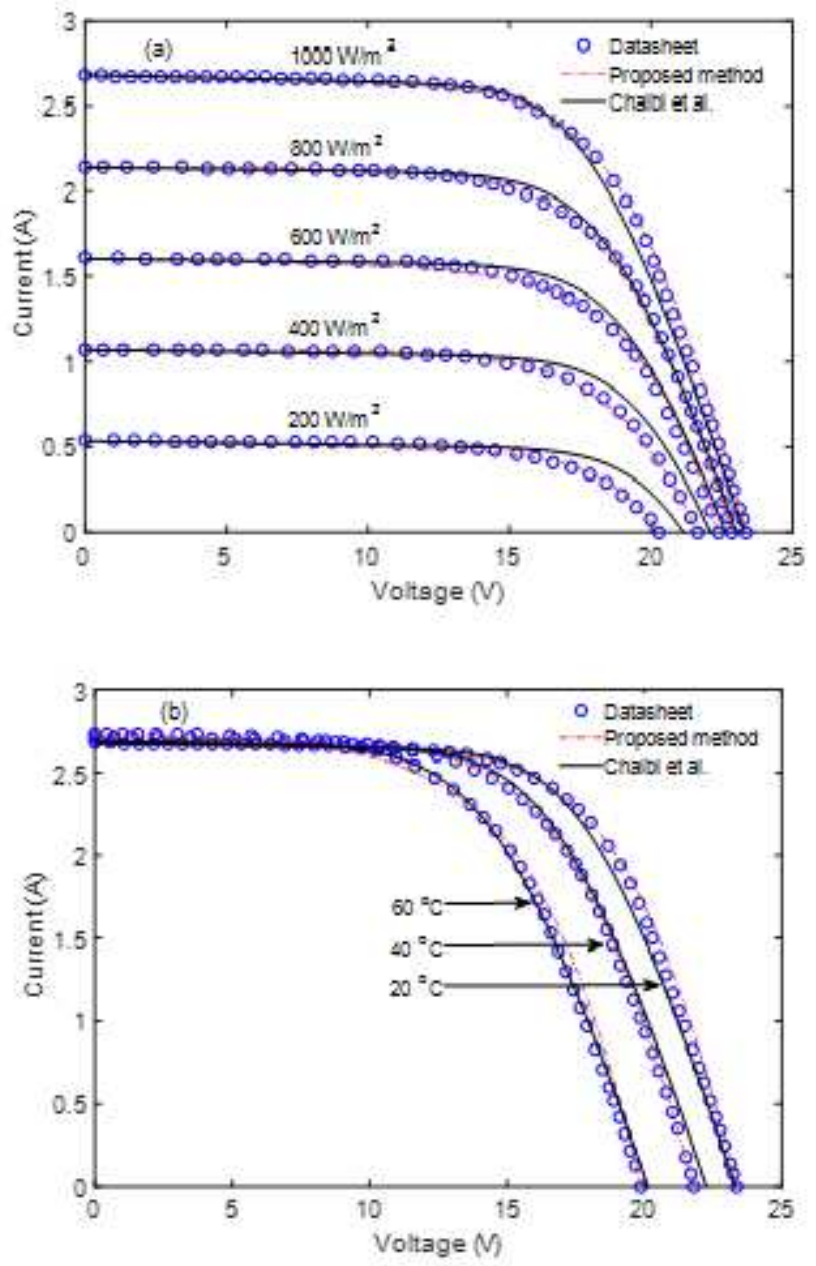

Figure 5

The datasheet and simulated I-V curves of the ST40 PV module under (a) uniform change of irradiance and fixed $T=25 \mathrm{oC}$, and (b) uniform change of temperature and $\mathrm{G}=1000 \mathrm{~W} / \mathrm{m} 2$. 